\title{
SUFISTIC THERAPY WITH SPIRITUAL EMOTIONAL FREEDOM TECHNIQUE (SEFT) METHOD FOR HEALING THE BEHAVIOR OF DRUGS ADDICT
}

\author{
Cintami Farmawati \\ Department of Sufism \& Psychotherapy, \\ Institut Agama Islam Negeri Pekalongan - Indonesia \\ e-mail: cintamifarmawati@gmail.com
}

\begin{abstract}
This research is to find out whether Sufistic therapy with the Spiritual Emotional Freedom Technique (SEFT) method can cure the behavior of addicts who seek drugs. Research subjects were 4 (four) drug addicts. The physical dependence on drugs that can be overcome by providing drugs with groups as substances commonly consumed to minimize them, but the hardest thing is to change the behavior of addicts who are looking for drugs and consume them again. This study uses a multiple baseline design with $\mathrm{AB}$ follow-up design where $\mathrm{A}$ is the baseline, B is a Sufistic therapy with SEFT method which allows the stages of set-up, tune in, and tapping, as well as follow-up. Data analysis in this study uses quantitative analysis and qualitative analysis. The quantitative analysis in this study is in the form of graphical explanations of research, while the qualitative analysis is the result of observations and interviews during the research. The results of this study indicate that the hypothesis is accepted where Sufistic therapy with the SEFT method can cure the behavior of addicts who seek drugs.
\end{abstract}

\begin{abstract}
Abstrak: Penelitian ini adalah untuk mengetahui apakah terapi sufistik dengan metode Spiritual Emotional Freedom Technique (SEFT) dapat menyembuhkan perilaku pecandu yang mencari narkoba. Subjek penelitian adalah 4 (empat) orang pecandu narkoba. Ketergantungan secara fisik terhadap narkoba dapat diatasi dengan memberikan obat-obatan dengan golongan sejenis sebagai pengganti zat yang biasa dikonsumsi untuk meminimalisir gejala putus zat, namun hal yang tersulit adalah mengubah perilaku pecandu yang mencari narkoba dan mengkonsumsi kembali. Penelitian ini menggunakan rancangan multiple baseline design dengan desain $\mathrm{AB}$ follow-up dimana $\mathrm{A}$ merupakan baseline, B merupakan terapi sufistik dengan metode SEFT yang meliputi tahapan the set-up, the tune in, dan the tapping, serta follow-up. Analisis data dalam penelitian ini menggunakan analisis kuantitatif dan analisis kualitatif. Analisis kuantitatif dalam penelitian ini berupa penjelasan grafik penelitian, sedangkan analisis kualitatif berupa hasil dari observasi dan wawancara selama penelitian. Hasil penelitian ini menunjukkan bahwa hipotesis diterima dimana terapi sufistik dengan metode SEFT dapat menyembuhkan perilaku pecandu yang mencari narkoba.
\end{abstract}

Keywords: the addict of drugs; sufistic therapy; SEFT method 


\section{A. Introduction}

Narcotics are chemicals that change a person's mood or behavior when smoking, injecting, drinking, sucking, or swallowing in the form of pills. Drug abuse is defined as a maladaptive pattern of drug use that occurs in a 12-month period that leads to significant setbacks or evidence of distress followed by one or more of the following: 1) failure to carry out tasks or responsibilities, 2) using substances in situations physical harm, 3) legal problems, 4) interpersonal problems. ${ }^{1}$

Drug abuse is a national threat that needs to be considered in a multidimensional manner, both in terms of micro (family) and macro (national) aspects. But in terms of the type of substance, drug dependence is a mental and behavioral disease that has an impact on the psychiatric condition in question and causes various social problems to criminal acts. The threat of the dangers of drugs has grown rapidly and is worrying for the community, especially drug abuse has now reached the level of elementary and rural schools. ${ }^{2}$

The rehabilitation program intended for drug addicts to stop addiction is not a difficult problem, because many people can stop using drugs for some time. The thing that is difficult to do is to prevent it from getting relapse. Relapse is a drug reuse behavior after running rehabilitation treatments that are characterized by thoughts, behaviors and addictive feelings after 3 periods of withdrawal. According to the World Health Organization (WHO), a person is said to have recovered from drug dependence if he has been free or clean of drugs for at least 2 years. ${ }^{3}$

Physical dependence on drugs tends to be easily overcome by giving drugs of the same type as a substitute for substances commonly consumed to minimize symptoms of withdrawal, but the most difficult thing is to change addictive behavior oriented to drug-seeking behavior. This is the cause of exaddicts who have completed relapse rehabilitation using drugs. What is

${ }^{1}$ Richard P. Halgin and Susan Krauss Whitbourne, Psikologi Abnormal: Perspektif Klinis Pada Gangguan Psikologis (Jakarta: Salemba Humanika, 2010), 75.

${ }^{2}$ Fadrian Menthan, "Peranan Badan Narkotika Nasional Kota Samarinda dalam Penanggulangan Masalah Narkoba di Kalangan Remaja Kota Samarinda," EJournal Administrasi Negara 1, no. 2 (2013): 544-57

${ }^{3}$ Syuhada, "Faktor Internal dan Intervensi pada Kasus Penyandang Relaps Narkoba," in Seminar Psikologi \& Kemanusiaan, 2015, 35. 
worrying is the high rate of drug users comparable to the high rate of relapse in drug users. The recurrence rate of addicts who have been treated at various therapy and rehabilitation centers is higher, namely $60 \%$ to $80 \%{ }^{4}$

Faried curing drug addicts requires a lot of time and also takes a lot of energy and mind, and requires a name such as science, expertise, and patience that is quite high in dealing with drug addicts. Healing drug sufferers can be done in various diverse and different ways, such as using the spirituality of religious preaching and love. 5 There is one time the method of religious spirituality is quite affective to cure people with drugs, but there is a time when they cannot cure drug sufferers. In fact, there could be cases when the method of religious spirituality is forcibly applied to the sufferer, making the sufferer even worse and becoming increasingly into the abyss of drugs. Many drug sufferers fight when they are always blamed and cornered.

Treating diseases caused by mental disorders in this case drug addicts is also included experts usually use certain techniques to find the causes of the occurrence of the disorder. For example, hypnosis techniques, suggestions, psychoanalysis and others. While Imam Shafi'i Mufid by following the theory of al-Ghazali, provides an alternative how to treat themselves from psychiatric disorders, namely: "The first thing to do is muḥ̄ssabah, which examines his own daily behavioral actions that are the cause and source of anxiety. ${ }^{6}$

Badan Narkotika Nasional (BNN) of Batang District has one room for rehabilitation of drug addicts. BNN of Batang District has a rehabilitation and post-rehabilitation program for drug addicts. In 2018, BNN of Batang District has a target of 30 drug addicts to participate in the Rehabilitation and PostRehabilitation program at the BNN of Batang District. The 30 participants divided into 3 groups and each group consisted of 10 people to attend the therapy session. Group therapy carried out at BNN of Batang District is still focused on development and resilience.

${ }^{4}$ Lydia Harlina Martono, Modul Latihan Pemulihan Pecandu Narkoba Berbasis Masyarakat (Jakarta: Balai Pustaka, 2005), 55; Tim Penyusun BNN, Survei Prevalensi Penyalahgunaan Narkoba Pada Kelompok Rumah Tangga di 20 Provinsi Tahun 2015 (Jakarta: Pusat Penelitian Data dan Informasi Badan Narkotika Nasional, 2016).

${ }^{5}$ Ahmad Faried, Menyucikan Jiwa (Surabaya: Risalah Gusti, 2003), 75.

${ }^{6}$ Dadang Hawari, Penyalahgunaan dan Ketergantungan Napza, Narkotika, Alkohol dan Zat Adiktif(Jakarta: FKUI, 2008), 65.

JURNAL THEOLOGIA — Volume 30, No. 1, June 2019 
The personal interview of the researcher at the BNN of Batang District office against SB (age 15 years), a drug addict who still relapsed frequently, obtained the interview quote as follows: "At first I was invited by a friend and wanted to try it turned out to be good, already rehabilitated also but because it is still with my friends sometimes there is little to try again and use drugs ".7 Departing from the problems above, then a serious treatment is needed to cure the behavior of addicts who are looking for post-rehabilitation drugs so that they can prevent relapse. The therapeutic process in this study uses sufistic therapy with the SEFT (Spiritual Emotional Freedom Technique) method.

Sufic therapy is a treatment and healing therapy that aims to restore balance, wholeness and unity between the physical and metaphysical worlds that integrate physical, mental, emotional and spiritual dimensions. ${ }^{8}$ Whereas, SEFT (Spiritual Emotional Freedom Technique) is a revolutionary and spectacular scientific technique because the results are very easy and fast to be able to feel in overcoming various physical, emotional, family problems, life success, peace of mind and happiness. ${ }^{9}$ Sufistic therapy with the SEFT method is a healing process as well as preventive, curative and development that focuses on sincerity, submission and gratitude for various situations or problems experienced by someone. ${ }^{10}$ Sufistic therapy with the SEFT method is used to help clients who experience physical or psychological problems with drug addicts.

The results of the study by Bakri and Barmawi explained that rehabilitation through da'wah namely: teaching Islamic religious adherence to patients, forming a strong Muslim personality, reinvesting the spirit of faith and devotion in the soul, educating patients to practice religion, instilling Islamic values through an individual approach, teaching or giving practices that can make drug addicts aware of their bad habits of consuming drugs. ${ }^{11}$ Other than that, the

\footnotetext{
${ }^{7}$ Author's interview to one of the drug addicts who underwent rehabilitation at BNN of Batang District, September 29, 2018.

${ }^{8}$ R.N.L. O'riordan, Seni Penyembuhan Alami: Rahasia Penyembuhan Melalui Energi Ilahi, ed. Sulaiman al-Kumayi (Bekasi: Gugus Press, 2002), 45.

${ }^{9}$ Ahmad Faiz Zainuddin, Spiritual Emotional Freedom Technique (SEFT) for Healing + Success + Happiness + Greatness (Jakarta: Afzan Publishing, 2009), 3.

${ }^{10}$ Cintami Farmawati, "Spiritual Emotional Freedom Technique (SEFT) Sebagai Metode Terapi Sufistik," Madaniyah 8, no. 1 (2018): 75-94.

${ }^{11}$ Nurdin Bakri and Barmawi Barmawi, "Efektifitas Rehabilitasi Pecandu Narkotika Melalui Terapi Islami di Badan Narkotika Nasional (BNN) Banda Aceh," Psikoislamedia : Jurnal Psikologi 2, no. 1 (2017): 86-95, https://doi.org/10.22373/psikoislamedia.v2i1.1827.
} 
research of Mulkiyan and Farid revealed that in the stages of healing methods of drug addicts applied in the BNN Baddoka Rehabilitation Center Makassar there are four stages, namely the detoxification, psychological, social and religious stages in solving problems faced by drug addicts. ${ }^{12}$

The research by Faruk (2014) states that there is a relationship between psychological therapy on drug addicts in the At-Tauhid Rehabilitation Islamic Boarding School Semarang. ${ }^{13}$ Whereas according to the study of Hikmatullah (2017), drug addict patients were rehabilitated with spiritual therapy, namely constant remembrance therapy and fasting which was supported by breathing and motion therapy and electrical therapy. Throughout the knowledge of researcher that sufistic therapy with the SEFT method is very interesting for researchers to investigate further in carrying out sufictic therapy with SEFT method for healing the behavior of addict who are looking for drugs.

Based on the above background, the researcher wanted to examine sufistic therapy with the SEFT method to cure addicts who sought drugs after completing the rehabilitation period and were already in a post-rehabilitation program. The selection of the SEFT method as sufistic therapy in this study is because it is easy, safe and practical.

\section{B. The Behavior of Narcotics Addicts Seeking Narcotics}

Drug addicts according to Article 1 Number 13 of Law Number 35 of 2009 say that drug addicts are people who use or abuse narcotics and are in a state of dependence on narcotics, both physically and psychologically. According to Jeffrey D. Gordon, drug addicts are someone who has experienced passion and obsession mentally and emotionally and physically. For addicts, there is nothing more important than getting drugs so that you will experience symptoms of drug withdrawal and pain. Based on the explanation, the researcher concluded that what is meant by drug addicts is someone who experiences physical and

\footnotetext{
${ }^{12}$ Mulkiyan Mulkiyan and Ach Farid, "Terapi Holistik terhadap Pecandu Narkoba," Konseling Religi 8, no. 2 (2017): 269-92, https://doi.org/10.21043/kr.v8i2.2753.

13Umar Faruk, "Terapi Psikoreligius Terhadap Pecandu Narkoba (Studi Analisis di Pondok Pesantren Rehabilitasi At-Tauhid, Semarang)” (Thesis, UIN Walisongo, 2014).
} 
psychological dependence on narcotics, psychotropic substances and addictive ingredients. ${ }^{14}$

Badan Nasional Narkotika (BNN) explain the level of drug abuse or the process of someone becoming an addict, including: 1) Abstinence. The period where a person does not use drugs at all for recreational purposes. 2) Social use. The period in which someone has started trying drugs for recreational purposes but has no impact on the user's social, financial and medical life. Users can still control the level of drug use. 3) Early problem use. Someone has misused addictive substances and the behavior of abuse has caused an effect on social life, a user such as lazy school, socializing only with certain people. 4) Early addiction. The condition of an addict who has shown dependency behavior both physically and psychologically and this behavior disrupts the social life in question. An addict is very difficult to adjust to normal life patterns, and tends to do things that violate the values and norms that apply. 5) Severe addiction. The period of someone who has lived to maintain his addiction, and has neglected his social life and self. At this stage, an addict has dared to commit criminal acts in order to fulfill the need for drug consumption.

Dadang Hawari mentions that there are three large groups of drug addicts and their risks. First, the primary dependency group is characterized by an unstable personality, experiencing disorders, anxiety and depression. They try to treat their own disorders without consulting a doctor so that abuse occurs to the level of dependence. Second, the symptomatic dependence group is characterized by the presence of anti-social (psychopathic) personality. They use drugs not only for themselves, but also transmit it to others in various ways so that other people can get caught up in using it until they experience a similar dependency. Third, the group is reactive dependency. Reactive dependency groups are mainly found in adolescents because of their curiosity, environmental influences and peer group pressure. 15 The types of drugs that are abused include:

1. Narcotics. According to Law No. 9 of 1976, the types of narcotics come from three groups of ingredients or plants, namely (a) Group I Narcotics, derived

14Tina Alfiatun, Pencegahan Penyalahgunaan Narkoba dengan Program Aji (Yogyakarta: Gadjah Mada University Press, 2010), 65.

${ }^{15}$ Hawari, Penyalahgunaan dan Ketergantungan Napza, Narkotika, Alkohol dan Zat Adiktif, 67. 
from opium plants or Paper Somniverum L (Opium or Opioda) known as morphine and heroin. Prolonged use creates a feeling of dependence; (b) Group II Narcotics, derived from Koka plants or Eritroxylon Caca which is known as Cocaine as a stimulant for the central nervous system. Excessive use will cause convulsions followed by the emergence of heart dysfunction, which ultimately can be fatal to the wearer; (c) Group II Narcotics, derived from cannabis plants or Canabis Sativa. The use of marijuana results in increased heart rate work, the occurrence of respiratory organs disorders, causing tumors or cancer, and use during pregnancy can cause fetal abnormalities.

2. Psychotropic. According to Law Number 5 of 1997 concerning psychotropics. Psychotropic is a substance or drug, both natural and synthetic, not narcotics, which has psychoactive properties through selective influence on the central nervous system which causes distinct changes in mental and behavioral activities. Psychotropics are grouped into four, namely: (a) Depressant, is a sedative. Types of drugs that when used have the effect of reducing the activity of the central nervous system, so it is commonly used to facilitate sleep. Drugs classified as depressants are alcohol; (b) stimulants, drugs that work activate the work of the central nervous system such as ecstasy. The active substance contained in ecstasy is amphetamine, a substance classified as stimulant (stimulant); (3) Hallucinogens, the use of this drug can cause feelings of unreality, which can increase to hallucinations with wrong perceptions and lead to physical and psychological dependence and a fairly high tolerance effect. Drugs including hallucinogens include LSD (Lysergic Acid Dietilamide), PCD (Phencyclidine), DMT (For the sake of Thyltry Tamine); (d) Canabis Sativa, commonly called marijuana, when used will result in consciousness becoming weak.

3. Addictive Materials. Addictive ingredients are substances that can cause addiction, addiction or dependence. Addictive substances consist of: (a) Sedativa and Hypnosis: barbiturates, clonalhydrates and pardelhides; (b) Phensiclisides, substances known as serylin which are used for animal anesthesia and these substances are usually often mixed with marijuana; (c) Nicotine, found in tobacco plants; (d) Caffeine, is an alkaloid found in arabica, robusta and idopiliberica coffee plants; (e) Ihylasia and Solven. Substances 
that are classified in this type are gas and the substance is put in plastic and inhaled.

\section{Sufistic Therapy with the SEFT Method}

Sufistic therapy is a treatment and healing therapy that aims to restore balance, wholeness and unity between the physical and metaphysical worlds that integrate physical, mental, emotional and spiritual dimensions. ${ }^{16}$ Sufistic therapy presents a different picture of humans and their lives. Based on a very broad vision of who and what human beings are not limited to something that appears only in humans, but includes a higher, softer and more visible levels beyond the physical world.

Sufistic therapy believes that faith and closeness to God is a very significant force for mental problems. The various types of sufistic therapy are as follows, namely: Therapy for Repentance, Dhikr, Therapy of the Qur'an, Prayers and Prayer Therapy.17 According to Rajab, the psychotherapy methods used in sufistik mental health include Taubat, Zuhud, Sabar and Tawakal, Rida, Mahabbah and Ma'rifat, Khauf and Tawadhu, Takwa and Ikhlas, Syukur and Muthma'innah. ${ }^{18}$

Sufistic therapy with the SEFT method is healing or treatment with the SEFT method (Spiritual Emotional Freedom Technique), where individuals are brought to the belief that healing comes from God so that they can be sincere and surrender to the problems they experience. In addition, SEFT can increase faith and piety, overcome physical and emotional problems, maximize the potential and strength that exists in each individual, improve performance to achieve peak performance, clear emotional trash to achieve peace of mind and create harmonious relationships with others. Sufistic therapy with the SEFT method believes that faith and closeness to God is a very significant force for mental problems. ${ }^{19}$ Zainuddin (in Farmawati, 2018), the steps to conducting a SEFT are:

\footnotetext{
${ }^{16}$ O'riordan, Seni Penyembuhan Alami.

${ }^{17}$ Sudirman Tebba, Tasawuf Positif(Jakarta: Kencana, 2003), 87.

${ }^{18}$ Khairunnas Rajab and Akhiriyati Sundari, Obat Hati: Menyehatkan Ruhani dengan Ajaran Islami (Yogjakarta: Pustaka Pesantren, 2010), 45.

${ }^{19}$ Farmawati, "Spiritual Emotional Freedom Technique (SEFT)."
} 
1. The Set-Up. The Set-Up aiming to ensure the body's energy flow is directed appropriately. This step is done to neutralize psychological reversal (negative thoughts or unconscious beliefs). How to neutralize psychological reversal by doing set-up words. The set-up words are prayers of submission to Allah SWT. The example of the set-up words is "Oh Allah ... even though I am (your complaint), I am sincere, I surrender to You fully."

2. The Tune In. How to tune-in by thinking of specific events to generate negative emotions that will be eliminated. The goal is to neutralize negative emotions or physical pain that is felt. Another way to do a tune-in is to replace the reminder with the phrase "I am sincere, I surrender to You O God". Tune-in is done until all SEFT therapy techniques are carried out until the end.

3. The Tapping. The Tapping is tapping lightly with two fingertips at a point (certain key points "the major energy meridians" 20 in the body by continuing to tune-in).

4. Nine Gamut Procedure. Nine Gamut Procedure are nine movements to stimulate the brain. Every movement to stimulate certain parts of the brain. The nine movements are: closing the eyes, opening the eyes, moving the eyes firmly to the lower right, eye moving strongly to the lower left, turning the eyeball clockwise, turning the eyeball counterclockwise, muttering rhythmically for two seconds, counting one, two, three, four, and, five, and muttered again like step 7.

5. The Tapping Again. After completing the nine gamut procedure, the final step is to repeat the tapping and end with taking a deep breath and then exhaling. 21

\section{Sufistic Therapy with the SEFT Method to Cure the Behavior of Addicts Looking for Drugs (Relapse)}

The behavior of addicts who are looking for drugs is a condition where individuals who have completed the rehabilitation process and are in the post-

${ }^{20}$ The major energy meridians are points along the 12 energy pathways (energy meridians) of the body that affect human health. The key points of the major energy meridians, which if we knocka few times will have an impact on neutralization of emotional disturbances or pain that is felt, because the body's energy flow runs normally and is balanced again.

${ }^{21}$ Farmawati, "Spiritual Emotional Freedom Technique (SEFT).” 
rehabilitation period and fail to maintain healthy conditions so that they consume and seek drugs again. This addicted behavior is called relapse. Relapse is a progressive process that involves the emotional and behavioral process of an individual where in the end the individual returns to such conditions before he receives treatment for recovery.

According to Marlatt \& Donovans (2005) relapse can occur in addictions to alcohol, cigarettes, heroin, and other addictive substances and is estimated to reach 50\% - 90\% of addiction cases. Marlatt \& Gordon (1985) one of the main factors and plays an important role in the process of relapse is high-risk situations and individual responses to high-risk situations that will determine whether someone will relapse or not. Larimer etc (1999) identifies a series of situations commonly experienced by addicts and can trigger the emergence of relapse, namely: negative emotional situations, situations involving other people or groups of people that can cause interpersonal conflict, intrapersonal conflicts, social pressure, positive emotional situations, the desire to test self-control and addiction conditions / 'sugars'.22

Sufic therapy with the SEFT method is to teach an individual to reduce psychological problems such as addiction, anxiety, stress, phobia, insomnia, boredom, laziness, nervousness, insecurity and so on by using a finger and middle finger that is lightly tapped on several meridian points body. In addition, they were also given several conditioning programs to change the pattern of drug use by involving God in the process of energy psychology which made SEFT experience amplifying effects so that the spectrum of problems could be quickly resolved to change patterns of drug use.

Sufic therapy with the SEFT method in this study was used to cure addicts who sought drugs which included the set-up, the tune-in, and the tapping. ${ }^{23}$ The behavior of addicts who are looking for drugs in this study is measured through behavioral scales, which are self-report measuring instruments. Self report is a form of personality test in which respondents provide information about themselves by answering a number of questions, writing on personal notes or

${ }^{22}$ G. Alan Marlatt and Dennis M. Donovan, eds., Relapse Prevention: Maintenance Strategies in the Treatment of Addictive Behaviors, 2nd ed. (New York: The Guilford Press, 2005), 110.

${ }^{23}$ Farmawati, "Spiritual Emotional Freedom Technique (SEFT)." 
reporting various thoughts and/or behaviors. ${ }^{24}$ Based on several things that have been described above, this study was conducted to find out whether sufic therapy with the SEFT method will help heal addicts who are looking for drugs.

\section{Method}

This study uses the Quasi Experimental Single Case Design design, which is a research design used to evaluate the effect of a treatment (intervention) in a single case. ${ }^{25}$ The model used is Multiple Baseline Across Participant Designs.

Nock study uses multiple baseline design across participants with the A-B follow-up paradigm, where A is the baseline, B is therapy, and follow-up is the final measurement after follow-up with the same goal. ${ }^{26}$ Follow-up was carried out after being given a pause for 1 month to see whether the behavior of addicts who sought drugs persisted or recovered after completing sufistic therapy with the SEFT method.

The two main variables used in this study are 1) Free Variables: Sufistic Therapy with the SEFT Method; 2) Dependent Variables: The Behavior of Addicts Seeking Drugs. The subjects in this study were 4 (four) drug addicts. This study uses research subjects with the following characteristics: 1) Former addicts who have completed the rehabilitation process and are currently in the post-rehabilitation phase (after care phase); 2) Not experiencing Dual Diagnosis; 3) Never get SEFT-related therapy (Spiritual Emotional Freedom Technique); 4) Having normal / average intellectual abilities.

In this study the intervention used was sufistic therapy with the SEFT method. SEFT consists of 3 stages including the set-up, the tune-in, and the tapping. ${ }^{27}$ The therapist in this study is a psychologist who has minimal SEFT therapy certification at the therapist level.

\footnotetext{
${ }^{24}$ Ronald Jay Cohen Mark Swerdlik, Psychological Testing and Assessment An Introduction to Tests and Measurement, 7th ed. (New York: McGraw-Hill, 2005), 95.

${ }^{25}$ Latipun, Psikologi Eksperimen (Malang: UMM Press, 2011), 58.

${ }^{26}$ Matthew K. Nock, "A Multiple-Baseline Evaluation of the Treatment of Food Phobia in a Young Boy," Journal of Behavior Therapy and Experimental Psychiatry 33, no. 3-4 (2002): 217-225, http://projects.iq.harvard.edu/files/nocklab/files/nock_2002_multiplebaseline_eval_foodphobia_youngboy_btep.pdf.

${ }^{27}$ Farmawati, "Spiritual Emotional Freedom Technique (SEFT).”
} 
The scale used by researchers to measure addictive behavior seeking drugs, namely Alcohol and Drug Relapse Warning Scale consisting of 16 items, included aspects of Emotional Relapse, Mental Relapse and Physical Relapse. The higher the score obtained by the subject, the higher the relapse tendency in the subject. Conversely, if the score obtained by the subject is low, the tendency of the relapse that belongs to the subject is lower. Answer statements from each statement are provided as many as 4 answer choices, namely: Strongly Agree $=$ 1 , Agree $=2$, Disagree $=3$, Strongly Disagree $=4$.

In addition to the scale, interviews were conducted as additional data used for qualitative analysis. The interview in this study aims to obtain an overview of the condition of the subject related to the relapse of drug addicts he experienced. In this study researcher used semi-structured interviews and direct interviews. Interviews were conducted at baseline, therapy and follow-up and influential matters will be recorded as explanations to complement existing data.

The implementation of observations is carried out semi-structured during the research process. The researcher will observe mainly related to the physical condition of the subject in general, the behavior that emerged during the interview at the baseline, the implementation of sufistic therapy with the SEFT method and at follow-up and during filling Alcohol and Drug Relapse Warning Scale.

The research procedures in this study include: 1) Screening. Screening is done by interviewing and observing as the initial data to get a subject that matches the predetermined criteria. After going through the screening stage, subjects who had the criteria for the research subject were asked for approval as subjects and signed informed consent; 2) Baseline. Before being given treatment, the subjects measured the severity of the symptoms of relapse through Alcohol and Drug Relapse Warning Scale as the baseline. Baseline is done every 7 days felt by the subject. After baseline measurement, the subject received treatment. During treatment, the subject is observed and the results are recorded as observation data; 3) Treatment. Giving treatment in the form of sufistic therapy with the SEFT method is carried out for 5 sessions every 7 days with approximately 60 minutes per session. Measurement of the results of therapy is carried out after the therapy is given equipped with the results of observations and interviews during therapy; (4) Follow-up. Follow-up was done one month after the therapy was completed. Measurements are carried out every seven days for three weeks. Alcohol and Drug Relapse Warning Scale is filled by the subject 
itself because it is self-report. Alcohol and Drug Score Relapse Warning Scale as data at follow-up and completed with data from interviews and observations. Follow-up functions to see whether the relapse symptoms of drug addicts remain low after therapy is stopped.

Data analysis in this study was carried out by quantitative analysis and qualitative analysis. The quantitative analysis in this study is in the form of symptoms of relapse disorders that will be displayed in the form of Alcohol and Drug Relapse Warning Scale charts from the results of baseline, therapy, and follow-up. Qualitative analysis is done by looking at the decrease in relapse symptoms that affect the physical condition, behavior and activity before, during and after receiving therapy. Data obtained through observation and interviews.

\section{Results}

The subjects in this study were a 15 years-old boy and currently in grade 3 of junior high school. Based on the results of research in the field, an alhcohol and drug relapse warning scale score was obtained, there was a decrease in the recurrence rate for drugs on the subject, furthermore can be seen in the Table 1.

Based on the assessment results, get baseline thoughts on the subject, namely the existence of pessimistic thoughts about the future, guilt and blame by the environment, suicidal thoughts and useless self-beliefs. Based on baseline behavior, subjects also experienced symptoms of heart palpitations, cold sweats and pain/dizziness without physiological causes. The following is an explanation of the graphs of mind, physical \& feeling conditions pre and post interventions in the research subject.

Table 1. Scor Alcohol and Drug Relapse Warning Scale

\begin{tabular}{|c|c|c|}
\hline \multirow{2}{*}{ Subject } & \multicolumn{2}{|c|}{$\begin{array}{c}\text { Scor Alcohol and Drug Relapse } \\
\text { Warning Scale }\end{array}$} \\
\hline & Pra Intervention & Pasca Intervention \\
\hline SA & 75 & 60 \\
\hline SB & 64 & 52 \\
\hline SC & 73 & 64 \\
\hline SD & 76 & 62 \\
\hline
\end{tabular}




\section{Subject 1 (SA)}
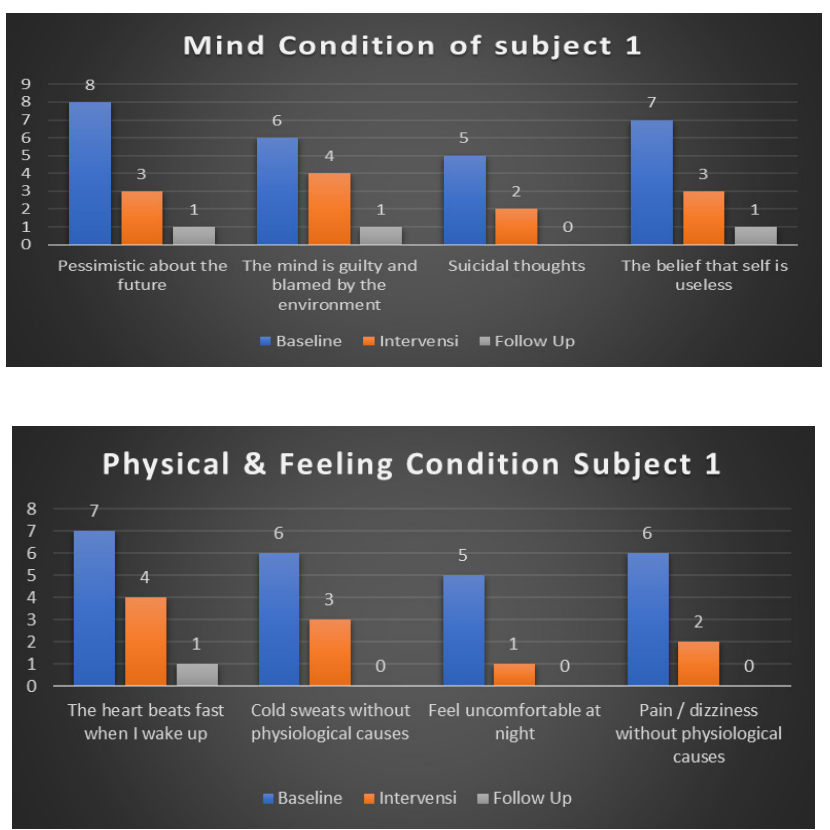

\section{Subject 2 (SB)}
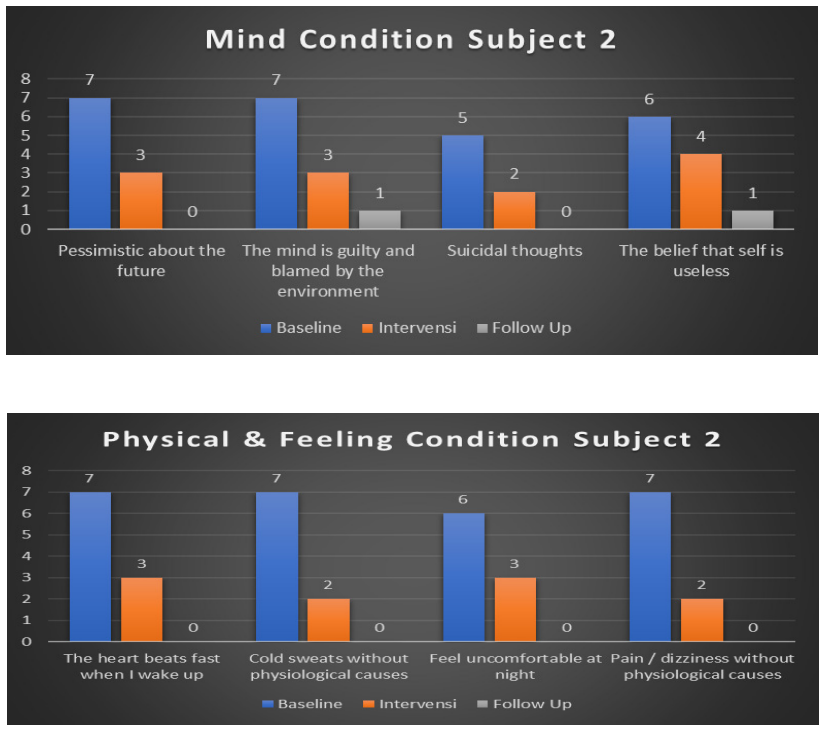


\section{Subject 3 (SC)}
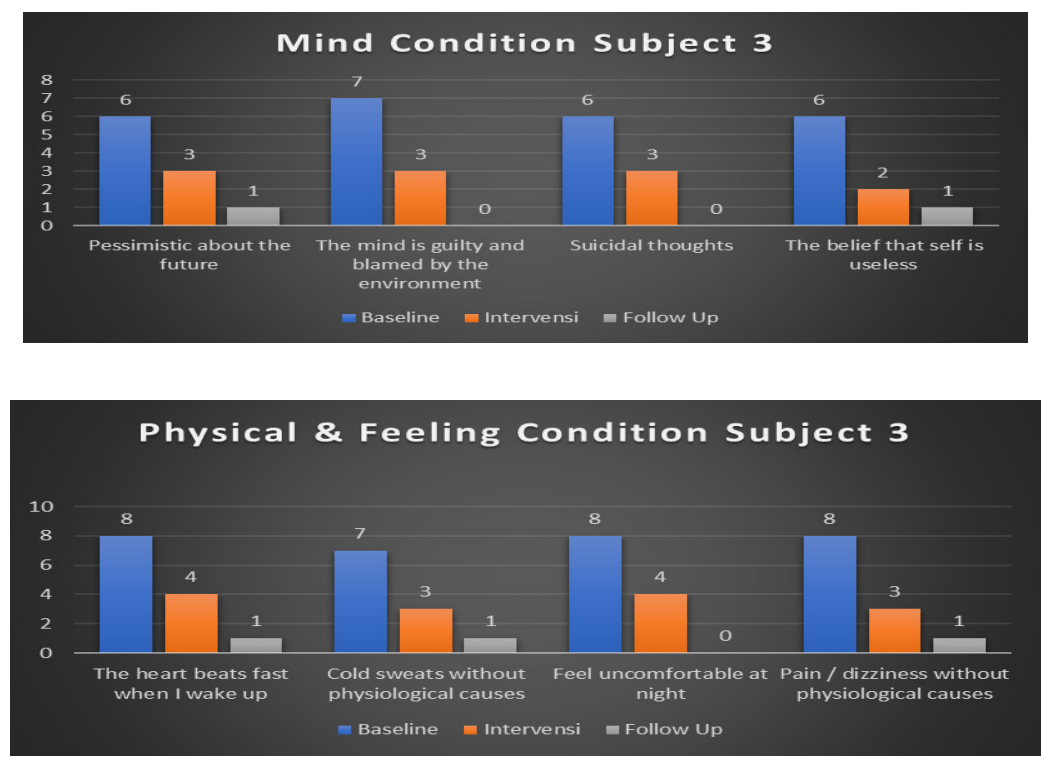

\section{Subjek 4 (SD)}
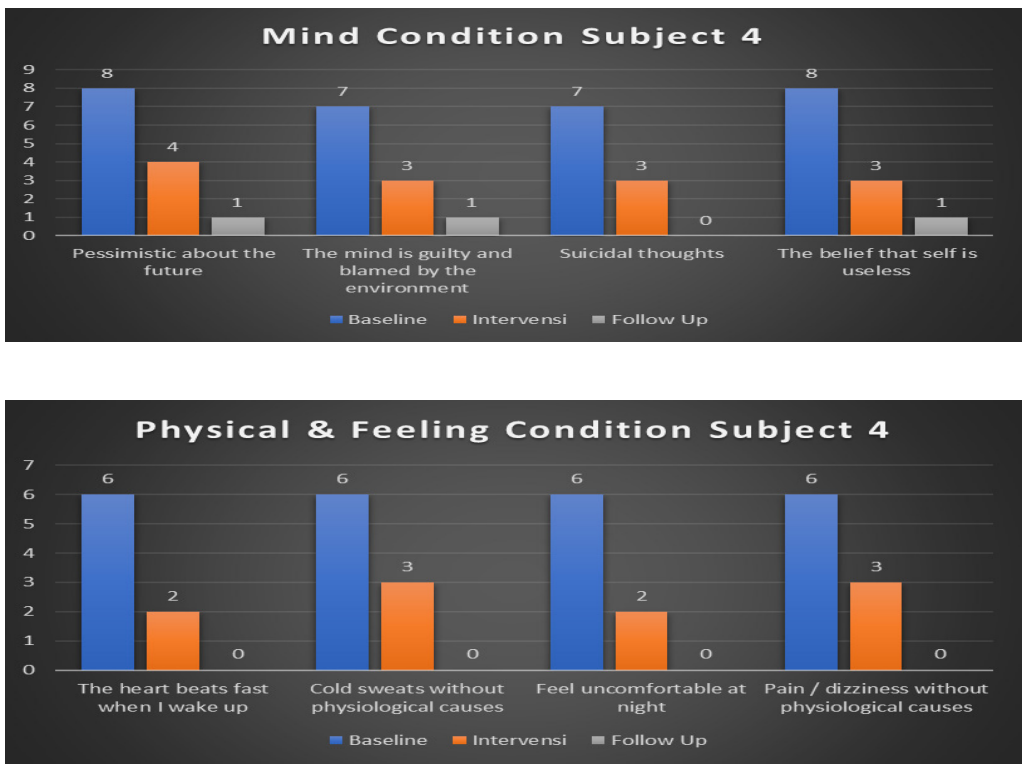

JURNAL THEOLOGIA — Volume 30, No. 1, June 2019 


\section{Discussion}

Subject 1 (SA) is a 15-years-old middle school student. SA is a closed individual. When starting a new relationship, the subject tends to be passive and will open communication if other people invite him. The environment outside the home is a comfortable place for the subject, while the home environment does not provide warmth. SA got to know marijuana type drugs in 2016 with initial trial, and over time SA tried to consume other types of drugs such as shabu and putaw, from 2017 the SA had stopped and then used drugs again until finally undergoing rehabilitation at BNN of Batang District.

The process of sufistic therapy with the SEFT method makes the SA more able to know itself, more aware that the past actions are not good, and the SA has the desire to be able to maintain that positive attitude. After being involved in being the subject of research, SA felt better than before about managing emotions, more calm, comfortable, and more could make his mind calmer. When undergoing a therapy session, SA cries more often. This is because when carrying out a therapy session, SA has a sense of guilt. During the sub-scale baseline session Alcohol and Drug Relapse Warning Scale does not decrease at all and only decreases during therapy. The aspect of the mind's condition of wanting to end life has decreased from 5 to 0 (lost) and shows a very good decline. In addition, SA has become more confident in facing the future, this can be seen from the pessimistic score on the future that was 8 to 1 .

Subject 2 (SB) is a schoolmate with SA, SB is now 14 years old. SB knows about methamphetamine drugs in 2016 from SA. Over time, SB continued to consume methamphetamine drugs until finally he often abandoned his duties as a student. In 2017, SB had stopped and then used drugs again until he finally underwent rehabilitation at the National Narcotics Agency on June 6, 2018 by his parents. SB has only received rehabilitation assistance for the first time to recover from the National Narcotics Agency. Previously, SB had never received rehabilitation at all, it was due to the lack of mental readiness and strong desire to recover.

SB feels the great benefits of giving therapy with the SEFT method to his rehabilitation process. At the initial meeting SB still did not feel the effects of the therapy, SB only said that he was a little calmer and his headaches were reduced. SB felt he could not practice therapy independently and understood better if he 
was guided by a therapist. SB also did not understand the purpose and purpose of the therapy he did. Besides the fairly dense conditions of activities in the rehabilitation therapy unit. After doing the therapy session, SB felt himself more fit and light, feeling more calm after the therapy session was over, SB was more stable in terms of emotions, and more open to his environment.

Subject 3 (SC) is 15 years old. SC recognizes methamphetamine drugs in 2016. Over time, SC continues to consume shabu-type drugs. In 2018, SC had stopped and then used drugs again until finally undergoing rehabilitation at the BNN. SC has received rehabilitation assistance twice to recover from the National Narcotics Agency. Previously SC was declared cured, and used drugs again because of a friend's invitation.

SC feels the great benefit of giving therapy with the SEFT method to the rehabilitation process. At the initial SC meeting, the effects of the therapy were still not too much, the SC only said that he was a little calmer and his headache was reduced. SC felt he could not practice therapy independently and understood better if he was guided by a therapist. SB also did not understand the purpose and purpose of the therapy he did. Besides the fairly dense conditions of activities in the rehabilitation therapy unit. After doing a therapy session, the SC feels he is healthier and stronger.

Subjects 4 (SD) recognized putaw type drugs in 2017. SD continued to consume putaw-type drugs until they often experienced anger. For five months, he stopped and then used drugs again until he finally underwent rehabilitation at the BNN. SD has just received rehabilitation assistance for recovery at the National Narcotics Agency. Previously SD had never experienced rehabilitation at all, it was caused by not wanting to quit drugs. At the beginning of being at the National Narcotics Agency in undergoing rehabilitation, SD felt bored with the situation in the Rehabilitation unit. Loneliness made him devastated. SD often feels headaches and has difficulty sleeping during the rehabilitation process. Sometimes SD don't eat all day because lose appetite.

SD felt helped by being made the subject of research, this made SD better, more able to overcome anger and boredom. SD explained that the condition was far better after partisipation in sufistic therapy using the SEFT method. SD successfully underwent his desire, which was immediately able to undergo the rehabilitation process well and smoothly, without having to lose appetite and headaches. SD also feels more comfortable, calm, relaxed, and fresher. 
The shortcomings of the study which also became a limitation of the study were: 1) The tight schedule and rehabilitation program so that researchers have difficulty in setting the scheduled routine therapy time with the research subject. 2.) The measurement of pretest, and posttest, using the same scale at the same time ( 2 months), can cause bias because the subject is familiar with the contents of the scale. 3) Subject personality factors can affect the results of research on subjects with closed personalities who will feel uncomfortable in undergoing therapy. 4) Other factors outside the subject vary, such as the environment of rehabilitation, family support and other factors that cannot be controlled by the researcher.

\section{Conclusion}

Based on the results and discussion, sufistic therapy with the SEFT method can reduce relapse symptoms in drug-seeking addicts experienced by all three subjects. Symptoms that can be derived are Emotional Relapse, Mental Relapse and Physical Relapse. This can be seen in baseline, therapeutic and follow-up measurements, ie the scores obtained from Alcohol and Drug Relapse Warning Scale at follow-up were lower than the scores obtained at the baseline.

The results showed that sufistic therapy with the SEFT method effectively reduced the symptoms of relapse as experienced by all four subjects. The results in the study showed that the symptoms included in the criteria for relapse of drug addicts decreased. The hypothesis in this study is accepted, namely that SEFT can cure addicts who seek drugs experienced by fourth subjects.

Subjects feel more calm, comfortable and more optimistic in undergoing treatment and motivated to recover. This proves that the administration of sufistic therapy with the SEFT method is effective in curing the behavior of addicts who are looking for narcotics in the rehabilitation program of BNN of Batang District. The results of this study are expected to add to the scientific repertoire of Sufism and psychotherapy and can be applied in daily life. By using this technique as a form of psychological intervention, as a complementary and as a form of therapy that becomes the main alternative, to overcome physiological and psychological disorders experienced by drug addicts.

Some of the shortcomings in this study can be used as a reference for conducting further research in the hope of improving the deficiencies in this 
study with different variables. Suggestions for future researchers, namely in finding subjects that meet the requirements, need to be considered for researchers who intend to conduct research using true experimental research design. Other than that, the use of the same scale in a time that is not close is at least 3 months to reduce bias when the subject is working on the pretest, and posttest, can be minimized by approaching and re-explaining the conditions being experienced by the subject, so that the subject can better understand and not affected by previous work.[]

\section{BIBLIOGRAPHY}

Alfiatun, Tina. Pencegahan Penyalahgunaan Narkoba dengan Program Aji. Yogyakarta: Gadjah Mada University Press, 2010.

Bakri, Nurdin, and Barmawi Barmawi. "Efektifitas Rehabilitasi Pecandu Narkotika Melalui Terapi Islami di Badan Narkotika Nasional (BNN) Banda Aceh." Psikoislamedia: Jurnal Psikologi 2, no. 1 (2017): 86-95. https://doi.org/ 10.22373/psikoislamedia.v2i1.1827.

Faried, Ahmad. Menyucikan Jiwa. Surabaya: Risalah Gusti, 2003.

Farmawati, Cintami. "Spiritual Emotional Freedom Technique (SEFT) sebagai Metode Terapi Sufistik." Madaniyah 8, no. 1 (2018): 75-94.

Faruk, Umar. "Terapi Psikoreligius terhadap Pecandu Narkoba (Studi Analisis di Pondok Pesantren Rehabilitasi At-Tauhid, Semarang)." Thesis. UIN Walisongo, 2014.

Halgin, Richard P., and Susan Krauss Whitbourne. Psikologi Abnormal: Perspektif Klinis Pada Gangguan Psikologis. Jakarta: Salemba Humanika, 2010.

Hawari, Dadang. Penyalahgunaan dan Ketergantungan Napza, Narkotika, Alkohol dan ZatAdiktif.Jakarta: FKUI, 2008.

Latipun. Psikologi Eksperimen. Malang: UMM Press, 2011.

Marlatt, G Alan, and Dennis M Donovan, eds. Relapse Prevention: Maintenance Strategies in the Treatment of Addictive Behaviors. 2nd ed. New York: The Guilford Press, 2005. 
Martono, Lydia Harlina. Modul Latihan Pemulihan Pecandu Narkoba Berbasis Masyarakat Jakarta: Balai Pustaka, 2005.

Menthan, Fadrian. "Peranan Badan Narkotika Nasional Kota Samarinda dalam Penanggulangan Masalah Narkoba di Kalangan Remaja Kota Samarinda." EJournal Administrasi Negara 1, no. 2 (2013): 544-57.

Mulkiyan, Mulkiyan, and Ach Farid. "Terapi Holistik terhadap Pecandu Narkoba." Konseling Religi 8, no. 2 (2017): 269-92. https://doi.org/10.21043/ kr.v8i2.2753.

Nock, Matthew K. "A Multiple-Baseline Evaluation of the Treatment of Food Phobia in a Young Boy." Journal of Behavior Therapy and Experimental Psychiatry33, no. 3-4 (2002): 217-225. http://projects.iq.harvard.edu/files/nocklab/ files/nock_2002_multiple-baseline_eval_foodphobia_youngboy_jbtep.pdf.

O'riordan, R.N.L. Seni Penyembuhan Alami: Rahasia Penyembuhan Melalui Energi Ilahi. Translated by Sulaiman al-Kumayi. Bekasi: Gugus Press, 2002.

Rajab, Khairunnas, and Akhiriyati Sundari. Obat Hati: Menyehatkan Ruhani dengan Ajaran Islami. Yogjakarta: Pustaka Pesantren, 2010.

Swerdlik, Ronald Jay Cohen Mark. Psychological Testing and Assessment An Introduction to Tests and Measurement. 7th ed. New York: McGraw-Hill, 2005.

Syuhada. "Faktor Internal dan Intervensi pada Kasus Penyandang Relaps Narkoba." In Seminar Psikologi \& Kemanusiaan, 2015.

Tebba, Sudirman. Tasawuf Positif. Jakarta: Kencana, 2003.

Tim Penyusun BNN. Survei Prevalensi Penyalahgunaan Narkoba Pada Kelompok Rumah Tangga di 20 Provinsi Tahun 2015. Jakarta: Pusat Penelitian Data dan Informasi Badan Narkotika Nasional, 2016.

Zainuddin, Ahmad Faiz. Spiritual Emotional Freedom Technique (SEFT) for Healing + Success + Happiness + Greatness. Jakarta: Afzan Publishing, 2009. 